\title{
Is rainfed agriculture really a pathway from poverty?
}

\author{
David Harris $^{*, 1}$, Alastair Orr \\ International Crops Research Institute for the Semi-Arid Tropics, East and Southern Africa, P.O. Box 39063, Nairobi, Kenya
}

\section{A R T I C L E I N F O}

\section{Article history:}

Received 16 January 2012

Received in revised form 1 September 2013

Accepted 26 September 2013

Available online 30 October 2013

\section{Keywords:}

Rainfed crop profitability

Smallholders

Farm size

Income limits

Poverty

New technology

\begin{abstract}
A B S T R A C T
Agriculture's potential to reduce poverty at household level is explored for rainfed crop production in Africa and India. A literature survey of crop improvement and natural resource management interventions demonstrates that new technology can substantially increase net returns per hectare per cropping season. However, the median net income from improved technologies was only $\$ 558 /$ ha/season at 2005 Purchasing Power Parity (PPP) and a de facto limit of around $\$ 1700 /$ ha/season was identified, with values rarely exceeding $\$ 1000 /$ ha/season. These values for net returns from the literature were mostly derived from small-plot studies and are likely to be overestimates when technologies are implemented by farmers on larger areas. Crop production could be a pathway from poverty where smallholders are able to increase farm size or where markets stimulate crop diversification, commercialisation and increased farm profitability. For most smallholders, however, small farm size and limited access to markets mean that returns from improved technology are too small for crop production alone to lift them above the poverty line and the direct benefit will be improved household food security.
\end{abstract}

(C) 2013 Elsevier Ltd. All rights reserved.

\section{Introduction}

'Smallholders' chances of rising out of poverty depend directly on their ability to increase the productivity of their crop and livestock husbandry activities' (CGIAR, 2005).

Poverty reduction became a strategic objective for development in the 1990s. As donors prioritized poverty, however, they also de-prioritized agriculture. Aid spending on agriculture fell by 45\% in real terms between 1990 and 2005 (Islam, 2011). Shrinking budgets intensified the pressure on agricultural research to show it could directly reduce poverty. Among international agricultural research centres, where in 2000 budgets were back to the same level as the mid-1980s (Beintema and Stads, 2008), this resulted in agriculture being promoted as a 'pathway from poverty'. True, funding constraints have eased somewhat with the advent of new donors and a renewed consensus on the importance of agriculture for development. Nevertheless, these twin imperatives - the need to compete for scarce research funding and to demonstrate impact on poverty - continue to determine the market for agricultural research. Yet the rhetoric of poverty reduction and the emphasis on impact gloss over inconvenient truths about the structure of smallholder agriculture and variations in potential between different agricultural environments.

\footnotetext{
* Corresponding author. Tel.: +254 207224556 .

E-mail address: d.harris@cgiar.org (D. Harris).

1 Senior authorship is not assigned.
}

Agriculture's potential to reduce poverty is rarely contextualized in terms of the farm household, or the share of agriculture in household income, or the livelihood strategies that rural households have used to graduate from poverty. Conventionally, the benefits from new technology are measured in terms of higher yields or, less commonly, income per hectare, without reference to the size of landholding or to the actual benefits that can be expected for an individual household. Similarly, where the share of agriculture in total income is low, increasing agricultural productivity will have only a modest impact on total household income. A classic example is rainfed rice in Uttar Pradesh, India, where reducing yield loss from drought increased mean income by just $1 \%$, because rice accounted for only $9 \%$ of total household income (Singh et al., 2000). Thus, a livelihoods perspective may give a very different view of the benefits from new technology. Finally, the evidence suggests that the main driver of graduation from poverty has not been agriculture but income from non-farm sources. ICRISAT's village studies in semi-arid India show that while between 1975 and 2004 average income per capita rose by $114 \%$, only $4 \%$ of this increase came from agriculture and only $1 \%$ came from crop production (Badiani et al., 2007). The decisive role of non-farm income for poverty reduction is confirmed by results at the all-India level (Krishna and Shariff, 2011). Similarly, a multi-country study concluded that 'self-employment or entrepreneurship is the most frequent path out of poverty'. Income from agriculture came fourth, after income from wages or salaries and help from the extended family (Narayan et al., 2000).

Again, a universal model of agriculture as a pathway from poverty overlooks the diversity of agro-ecological zones and farming 
systems. This is particularly true of areas where crop production is predominantly based on direct rainfall. The drylands epitomize the 'complex, diverse, risk-prone' environments by-passed by the Green Revolution (Chambers, 1983). Sorghum and millets, for instance, are grown in 10 major farming systems where the probability of drought leading to crop failure is one year in three, and six in ten of the rural population lives on less than $\$ 1.25$ per day (ICRISAT and ICARDA, 2012). In addition, many farmers in these areas have poor access to markets. In southern Africa, for example, $75 \%$ of the rural population lives more than four hours by road from a major urban centre (Harvest Choice, 2011).

Doubts about the potential of rainfed agriculture to reduce poverty are part of a wider debate over 'the future of small farms' (Hazell et al., 2010). Since the 1960s, the consensus has been that equitable growth required a development strategy based on smallholder agriculture (Ellis and Biggs, 2001). This orthodoxy is now being challenged on several fronts: by those who believe that large farms are more efficient (Collier and Dercon, 2009), or that neoliberal policies have reduced the ability of small farmers to produce for the market, forcing them into non-farm activities and accelerating a process of 'de-peasantisation' (Bryceson, 2002), or that rural non-farm employment and urban migration offer higher returns than agriculture (Ellis, 2005). At the heart of this debate lies the future of smallholder agriculture in SSA, where $80 \%$ of farms are now below 2 ha (Nagayets, 2005; Bélières et al., 2013). Shrinking farm size has serious implications for poverty reduction, suggesting that the majority of African farms may simply be too small for agriculture to be a viable pathway from poverty. Given the present agrarian structure, therefore, current strategies to reduce poverty directly through improving yields or access to markets may benefit only a small minority of smallholders.

The implications of small farm size for strategies to reduce poverty have been addressed in two seminal papers by Jayne et al. (2003, 2010). In this article, we extend their argument to explore the implications for agricultural research. Our general objective is to test the hypothesis that the benefits from agricultural research for rainfed agriculture can raise household incomes sufficiently to reduce poverty. Specifically, we ask four questions:

1. What is the current net income from rainfed agriculture?

2. How much can new technology raise income per household?

3. What impact will this gain in income have on poverty?

4. What are the implications for the role of agricultural research in poverty reduction strategies?

We stress limitations of scope. The focus of the article is on crop production and we have excluded irrigated situations, livestock activities, fish-farming and other more investment-rich, intensive land-based enterprises. The geographic focus is on the semi-arid and dry sub-humid tropics of Africa and Asia (referred to for brevity as 'the drylands') where agriculture is predominantly rainfed (FAO, 2000). This is a synthetic essay that offers no new data. Rather, its originality lies in linking two separate literatures, on agricultural technology and on poverty dynamics. Our aim is not to provide definitive answers but to raise questions, challenge assumptions, and to suggest connections between farm size, new technology and livelihoods that deserve deeper investigation.

\section{Data and methods}

\subsection{Data}

\subsubsection{Household surveys}

The stylized facts about smallholder agriculture are captured in recent household surveys. Table 1 presents comparative data from ten surveys - nine covering seven countries in SSA plus one from India. Throughout this paper, we use these facts as a point of reference for our discussion of rainfed agriculture. The data refer only to farm households and exclude households without income from crops.

Five of the SSA surveys are national surveys that collected information on smallholder agriculture. The design of these surveys has been described elsewhere (Jayne et al., 2010). Of the remaining three surveys, two are local surveys in Malawi and Ethiopia (Asfaw et al., 2010; Simtowe et al., 2010). Although designed to collect baseline information for grain legumes, both surveys collected data for all major crops. In Ethiopia, the survey was made in three districts (Minjar-Shenkora, Gimbichu and Lume-Ejere) located in the Shewa region in the central highlands. The sample size was 700 farm households, representing a proportional random sample from 26 kebeles. In Malawi, the survey was made in four districts, three in the southern region (Chiradzulu, Thyolo, and Balaka) and one district (Mchinji) in the central region. Chiradzulu and Thyolo districts are centres of production for pigeonpea while Balaka and Mchinji are centres of production for groundnuts. The sample size was 594 farm households, representing a random sample from three randomly selected villages from each of the four sections in each district producing the most pigeonpea or groundnuts. Finally, the third survey is a national household survey of Malawi conducted by the National Statistical Office in 2007-2008. A total of 10,698 households were surveyed, of which 6586 had reliable income data. Of these rural households, 4837 (86\%) were defined as crop-producing households. Table 1 presents data for the sample crop-producing households, based on the published survey data (NEC, 2000a,b; GoM, 2000).

Household data for predominantly rainfed agriculture are available from ICRISAT's Village Level Studies (VLS) in India and West Africa. For India, the most recent data presents information for six villages in Andhra Pradesh, averaged over four crop years (2001-2004). The sample size for farm households included in both the first generation VLS in 1975-1978 and the new VLS in 2001-2004 was 269 households (Badiani et al., 2007, Table 9). Table 1 presents average data for the six villages. For West Africa, information is available for six villages in Burkina Faso, representing the three major agro-climatic zones of West Africa's semi-arid tropics. The villages were first surveyed in 1985 and re-surveyed in 2002 (Ndjeunga and Savadogo, 2002). The data refer to 115 households that were surveyed in both 1985 and 2002.

\subsubsection{Net returns from rainfed crop production}

A survey was made of improved technology available for dryland agriculture. Literature published since 2000 was surveyed for studies that either reported net returns directly or included input and output data to enable the calculation of net returns for a diverse collection of rainfed crop improvement technologies tested for a wide range of crops and countries. Since experiments where no improvements in yield or profitability were found are not reported, these results represent the 'best case' results for improved technology. We based our initial search on the CABI (www. cabdirect.org) database but additional reports from the grey literature were also included. The selection is representative rather than exhaustive. Table 2 lists the cases considered for this analysis. Of the 69 cases, 23 (33\%) are from India, and 44 (64\%) from SSA. In each case, the 'base' value is the net return, in $\$ /$ ha/per season (converted to 2005 Purchasing Power Parity, PPP) associated with either the farmers' practice or the 'control' in agronomic trials and surveys. The 'improved' value is the net return of the best-performing treatment or technology reported in that publication. Where original values represented annual returns in situations where there are two cropping seasons per year (e.g., in Kenya and Uganda), or where long-duration crops occupied land for more 
Table 1

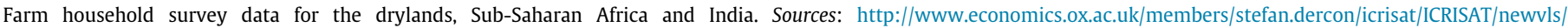
constructed.html

\begin{tabular}{|c|c|c|c|c|c|c|c|c|c|c|}
\hline & Malawi $^{\mathrm{A}}$ & Malawi $^{\mathrm{B}}$ & Ethiopia $^{\mathrm{C}}$ & Ethiopia $^{\mathrm{D}}$ & Kenya $^{C}$ & Rwanda $^{C}$ & Mozambique $^{C}$ & Zambia $^{\mathrm{C}}$ & B. Faso ${ }^{\mathrm{E}}$ & India $^{\mathrm{F}}$ \\
\hline Type of survey & National & Local & National & Local & National & National & National & National & $\begin{array}{l}\text { Village } \\
\text { studies }\end{array}$ & $\begin{array}{l}\text { Village } \\
\text { studies }\end{array}$ \\
\hline Sample size (no HHs) & 4837 & 594 & 2658 & 700 & 1416 & 1181 & 3851 & 6618 & 115 & 269 \\
\hline Year of survey & $\begin{array}{l}1997- \\
1998\end{array}$ & 2008 & 1996 & 2008 & 1997 & 1990 & 1996 & 2000 & 2001 & $\begin{array}{l}2001- \\
2004\end{array}$ \\
\hline Mean farm size (ha) & 0.96 & 1.07 & 1.17 & 2.24 & 2.65 & 0.94 & 1.8 & 2.81 & 21 & 2.30 \\
\hline Female-headed households (\%) & 26 & 24 & 17 & 7 & 18 & 18 & 14 & 24 & Na. & Na. \\
\hline Mean household size (No.) & 4.3 & 4.8 & 5.2 & 6.4 & 7.0 & 5.5 & 5.2 & 5.78 & 12.8 & 5.31 \\
\hline Adults of working age (15-64) & 2.2 & $2.4^{\mathrm{a}}$ & 2.8 & $3.5^{\mathrm{a}}$ & 3.7 & 2.7 & 2.7 & 3.2 & 6.1 & 3.05 \\
\hline Dependents/adults of working age & 0.9 & 1.1 & 0.9 & 1.0 & 0.9 & 1.0 & 0.9 & 0.8 & 1.1 & 1.12 \\
\hline $\begin{array}{l}\text { Mean income per household (2005 PPP } \\
\$ / \text { hh/year) })^{\mathrm{b}}\end{array}$ & 1095 & 1326 & 1505 & 2565 & 4235 & 229 & 218 & 400 & 3083 & 3031 \\
\hline $\begin{array}{l}\text { Mean net income from crop production } \\
(2005 \mathrm{PPP} \$ / \mathrm{hh} / \text { year })^{\mathrm{b}}\end{array}$ & $417^{\mathrm{c}}$ & 955 & $1385^{c}$ & 1999 & $2636^{\mathrm{c}}$ & $139^{c}$ & $144^{\mathrm{C}}$ & $303^{c}$ & 1808 & 978 \\
\hline $\begin{array}{l}\text { Proportion of income from crop production } \\
\text { (\%) }\end{array}$ & 38 & 72 & 92 & 78 & 34 & 70 & 84 & 67 & 60 & 24 \\
\hline $\begin{array}{l}\text { Proportion of income from off-farm sources } \\
\text { (\%) }\end{array}$ & 31 & 26 & 8 & 5 & 40 & 25 & 13 & 28 & 23 & 67 \\
\hline $\begin{array}{l}\text { Income/adult of working age from crop } \\
\text { production (2005 PPP \$/yr) }\end{array}$ & 189 & 398 & 495 & 571 & 712 & 52 & 53 & 95 & 296 & 321 \\
\hline
\end{tabular}

A NEC (2000a,b) and GoM (2000).

B Simtowe et al. (2010).

C Jayne et al. (2003), Jayne et al. (2001), Table 6 (FHHs) and App. Table A2.

D Asfaw et al. (2010).

E Ndjeunga and Savadogo (2002).

F Rao and Kumara Charyulu (2007);

a Calculated from original survey data.

b Values are in 2005 PPP US \$, calculated by converting current US \$ in the year of survey to current US \$ in 2005 obtained from World Development Indicators, and dividing by 2005 PPP values for final consumption (World Bank, 2008, Appendix Table S3).

c Mean net income from crop production excludes the cost of hired and family labour (Jayne et al., 2001, Appendix A).

than one season, these were divided by the number of seasons per year to be directly comparable with cropping at sites with just one season. Percentage increases over the available base case and benefit-cost ratios (BCRs) are also presented.

\subsection{Methods}

Costs and benefits of the base and improved technologies were converted to current US dollars using the market exchange rates at the time each study was conducted. Current dollar values were then converted to Purchasing Power Parity (PPP). The PPP values are based on household final consumer expenditure obtained by the International Comparison Program (ICP) for the benchmark year 2005 (World Bank, 2008). Since no PPP based on final consumption expenditure is available for Zimbabwe because results from the 2005 ICP were found unreliable (Ravallion et al., 2008), we used the 2005 PPP value for Zimbabwe Gross National Product.

To evaluate the benefits of improved technology at the household level, we considered the international poverty line (IPLs) of $\$ 1.25$ per day per capita, expressed in 2005 PPP, developed by the World Bank (Ravallion et al., 2008). In total, information on national poverty lines (NPLs) is available for 75 countries. The $\$ 1.25$ per day IPL is the mean PPP value of the NPLs for the 15 poorest countries, including 13 countries in SSA but excluding India, which is not among the 15 poorest. Thus, the $\$ 1.25$ IPL represents an absolute poverty line or the bare minimum required for subsistence in the world's poorest countries. By contrast, the $\$ 2$ per day IPL is a relative poverty line. Above this point, NPLs rise sharply with rising consumption. The \$2 per day IPL is the median 2005 PPP value for all 75 developing countries (Ravallion et al., 2008). Thus, the two IPLs represent the lower and upper bounds of the actual poverty line. Here, we use $\$ 1.25$ per day because this is the IPL used by the Millennium Development Goal target of halving global poverty by 2015 .
To estimate average values for 'base' and 'improved' technology, boxplots were used to identify extreme cases and outliers for the three variables, existing technology, improved, and difference between existing and improved. Five cases were subsequently dropped from the analysis (Das et al., 2008; Guto et al., 2011; Mazvimavi and Twomlow, 2009; Nedunchezhiyan, 2010; Prasad et al., 2010). The median values computed for the remaining 64 cases were 186 \$/ha/season for 'base' and 558 \$/ha/season for 'improved' technologies (Table 3).

'Net income' per ha from crop production was defined as gross returns minus variable costs, including the cost of family labour. It may be objected that this is inappropriate since peasant farms are subsistence rather than commercial enterprises. This is an old debate (Thorner, 1981). In practice, peasant farms are a hybrid, with one foot in the market and the other in the subsistence economy (Ellis, 1993). We have assumed that the published studies listed in Table 2 valued labour based on the market wage rate. Of the 69 interventions in Table 2, only 16 separated labour from other input costs. For pooled base and improved interventions, the median share of labour in total variable costs averaged $61 \%$. Nevertheless, we believe there is a strong case for including the cost of labour.

Including labour costs, whether hired or family, is standard procedure for the evaluation of improved technology. 'In no case should the opportunity cost of labour be set at zero' (CIMMYT, 1988: 18). It is inconsistent to include the cost of labour to evaluate the benefits of new technology only to exclude the cost of labour once that technology has been adopted. Second, resource-poor farmers have rejected seemingly profitable new technology that requires additional labour (Anderson, 1992). We can multiply examples. The System of Rice Intensification in Madagascar and Conservation Agriculture in Zimbabwe are cases in point (Moser and Barrett, 2003; Baudron et al., 2012). The opportunity cost of family labour is highest for poorer, food-deficit households because the peak period for agricultural labour in the first six weeks 
Table 2

Net returns for worst (base) case and best intervention (improved) reported since 2000 for crop- and natural resource management interventions in rainfed crop production.

\begin{tabular}{|c|c|c|c|c|c|c|c|c|c|c|}
\hline \multirow[t]{2}{*}{ Intervention } & \multirow[t]{2}{*}{ Crop } & \multicolumn{2}{|c|}{$\begin{array}{l}\text { Net returns (\$/ha/ } \\
\text { season) Current US } \\
\$\end{array}$} & \multicolumn{2}{|c|}{$\begin{array}{l}\text { Net returns (\$/ha/ } \\
\text { season) } 2005 \text { PPP }\end{array}$} & \multirow[t]{2}{*}{$\begin{array}{l}\text { Increase } \\
(\%)\end{array}$} & \multicolumn{2}{|c|}{ Benefit:cost ratio } & \multirow[t]{2}{*}{ Country } & \multirow[t]{2}{*}{ Reference } \\
\hline & & Base & Improved & Base & Improved & & Base & Improved & & \\
\hline \multicolumn{11}{|l|}{ a. Tillage } \\
\hline Zai planting basins + manure & Sorghum, cowpea & 0 & 127 & 0 & 276 & b & & & $\begin{array}{l}\text { Burkina } \\
\text { Faso }\end{array}$ & $\begin{array}{l}\text { cited by Haggblade } \\
\text { et al. (2004) }\end{array}$ \\
\hline Tillage + fertilizer (Inceptisol) 9 years & Pearl millet & 207 & 254 & 587 & 721 & 23 & 1.93 & 2.33 & India & $\begin{array}{l}\text { MaruthiSankar et al. } \\
\text { (2012) }\end{array}$ \\
\hline Tillage + fertilizer (Vertisol) 9 years & Pearl millet & 153 & 285 & 434 & 809 & 86 & 1.89 & 3.52 & India & $\begin{array}{l}\text { MaruthiSankar et al. } \\
\text { (2012) }\end{array}$ \\
\hline Tillage + fertilizer (Aridisol) 9 years & Pearl millet & 44 & 86 & 125 & 244 & 95 & 1.12 & 1.26 & India & $\begin{array}{l}\text { MaruthiSankar et al. } \\
\text { (2012) }\end{array}$ \\
\hline Tied ridges + fertilizer & Maize & 51 & 255 & 118 & 589 & 400 & & & Kenya & Gichangi et al. (2007) \\
\hline Tied ridges + fertilizer & Common bean & 129 & 367 & 298 & 848 & 185 & & & Kenya & Gichangi et al. (2007) \\
\hline Tassa planting basins & Pearl millet & 0 & 99 & 0 & 195 & b & & & Niger & $\begin{array}{l}\text { cited by Haggblade } \\
\text { et al. (2004) }\end{array}$ \\
\hline Conservation farming - basins & Maize & 58 & 231 & 91 & 364 & 298 & & & Zambia & $\begin{array}{l}\text { cited by Haggblade } \\
\text { et al. }(2004)\end{array}$ \\
\hline Conservation farming, basins & Cotton & 73 & 183 & 115 & 289 & 150 & & & Zambia & $\begin{array}{l}\text { cited by Haggblade } \\
\text { et al. (2004) }\end{array}$ \\
\hline Soil ripping versus plowing & Maize & 61 & 133 & 96 & 210 & 118 & 1.4 & 1.81 & Zambia & Kabwe et al. (2007) \\
\hline Soil ripping versus plowing & Cotton & 76 & 91 & 120 & 144 & 20 & 1.62 & 1.67 & Zambia & Kabwe et al. (2007) \\
\hline Minimum tillage + fertilizer & Maize & 50 & 77 & 79 & 121 & 54 & & & Zambia & $\begin{array}{l}\text { cited by Haggblade } \\
\text { et al. (2004) }\end{array}$ \\
\hline Conservation farming - basins & Maize & 48 & 535 & 369 & 4115 & 1114 & 1.76 & 4.03 & Zimbabwe & $\begin{array}{l}\text { Mazvimavi and } \\
\text { Twomlow (2009) }\end{array}$ \\
\hline \multicolumn{11}{|l|}{ b. Rotations, fallows, intercropping } \\
\hline Mucuna rotation & Maize & -66 & 69 & -127 & 132 & b & & & Benin & $\begin{array}{l}\text { cited by Haggblade } \\
\text { et al. ( } 2004 \text { ) }\end{array}$ \\
\hline Improved fallows, Mucuna + fertilizer & Maize & 3 & 137 & 5 & 245 & 4400 & & & Cameroon & $\begin{array}{l}\text { cited by Haggblade } \\
\text { et al. }(2004)\end{array}$ \\
\hline Alley cropping & Soybean, safflower, tree products & 117 & 156 & 332 & 443 & 33 & 1.88 & 2.27 & India & Mutanal et al. (2009) \\
\hline Alley cropping, discounted @ 12\% & Soybean, safflower, tree products & 39 & 58 & 111 & 165 & 49 & 1.88 & 2.27 & India & Mutanal et al. (2009) \\
\hline Leucaena-based agroforestry & Cowpea, timber & 145 & 542 & 411 & 1538 & 274 & 1.86 & 3.17 & India & Prasad et al. (2010) \\
\hline Biomass retention, double cropping & Rice-vegetable sequences ${ }^{c}$ & 84 & 752 & 238 & 2134 & 795 & 0.46 & 1.82 & India & Das et al. (2008) \\
\hline Crop mixtures, intercropping & Wheat, lentil, toria & 101 & 437 & 287 & 1240 & 333 & 1.79 & 2.1 & India & Kumar et al. (2008) \\
\hline Intercropping & Maize, blackgram & 89 & 194 & 253 & 550 & 118 & 1.45 & 1.78 & India & Sheoran et al. (2010) \\
\hline Intercropping & Pigeonpea, maize $\mathrm{c}^{\mathrm{c}}$ & 123 & 346 & 349 & 982 & 181 & 2.61 & 2.75 & India & Marer et al. (2007) \\
\hline Rotations, tillage, intercropping & Maize, soybean & 247 & 435 (not sig) & 571 & 1006 & 76 & 1.81 & 2.14 & Kenya & Kihara et al. (2012) \\
\hline Rotation & Maize, soybean & 54 & 243 & 90 & 406 & 350 & 1.22 & 2.5 & Nigeria & Kolawole et al. (2007) \\
\hline Better rotations & $\begin{array}{l}\text { Wheat, sunflower, chickpea, lentil, rapeseed, vetch, } \\
\text { peas, sorghum }\end{array}$ & 339 & 482 & 454 & 646 & 42 & & & Turkey & Dogan et al. (2008) \\
\hline Mucuna relay crop & Rice, maize & 197 & 407 & 460 & 949 & 107 & 1.58 & 2.13 & Uganda & Kaizzi et al. (2007) \\
\hline $\begin{array}{l}\text { Watershed development, new crops, varieties } \\
\text { and crop sequences }\end{array}$ & Maize, soybean, mungbean, groundnut, watermelon ${ }^{c}$ & 246 & 601 & 657 & 1604 & 144 & & & Vietnam & $\begin{array}{l}\text { MulaRosana et al. } \\
\text { (2007) }\end{array}$ \\
\hline Sesbania fallows & Maize & 6 & 229 & 9 & 361 & 3700 & & & Zambia & $\begin{array}{l}\text { cited by Haggblade } \\
\text { et al. ( } 2004 \text { ) }\end{array}$ \\
\hline Fertilizer Tree Systems & Maize & 130 & 309 & 205 & 487 & 138 & & & Zambia & Ajayi et al. (2009) \\
\hline $\begin{array}{l}\text { c. Fertilizers and soil amendments } \\
\text { Phosphorus and biofertilizers }\end{array}$ & Pigeonpea $^{c}$ & 224 & 444 & 636 & 1260 & 98 & 2.51 & 4.09 & India & $\begin{array}{l}\text { Singh and Yadav } \\
(2008)\end{array}$ \\
\hline Fertilizer + FYM & Rice, niger & 175 & 303 & 497 & 860 & 73 & 2.07 & 2.21 & India & Gogoi et al. (2010) \\
\hline Fertilizer + organic inputs & Sesame & 54 & 248 & 153 & 704 & 359 & 1.39 & 2.43 & India & Deshmukh and \\
\hline
\end{tabular}




\begin{tabular}{|c|c|c|c|c|c|c|c|c|c|c|}
\hline \multirow[t]{2}{*}{ Intervention } & \multirow[t]{2}{*}{ Crop } & \multicolumn{2}{|c|}{$\begin{array}{l}\text { Net returns (\$/ha/ } \\
\text { season) Current US } \\
\$\end{array}$} & \multicolumn{2}{|c|}{$\begin{array}{l}\text { Net returns (\$/ha/ } \\
\text { season) } 2005 \text { PPP }\end{array}$} & \multirow[t]{2}{*}{$\begin{array}{l}\text { Increase } \\
(\%)\end{array}$} & \multicolumn{2}{|c|}{ Benefit:cost ratio } & \multirow[t]{2}{*}{ Country } & \multirow[t]{2}{*}{ Reference } \\
\hline & & Base & Improved & Base & Improved & & Base & Improved & & \\
\hline Fertilizer + mulching & Greater yam, maize ${ }^{c}$ & 34 & 633 & 96 & 1796 & 1762 & 0.46 & 0.73 & India & $\begin{array}{l}\text { Duhoon (2008) } \\
\text { Nedunchezhiyan } \\
\text { (2010) }\end{array}$ \\
\hline Fertilizer + mulching & Elephant's foot yam, green gram ${ }^{c}$ & 252 & 611 & 715 & 1734 & 142 & 1.43 & 2.02 & India & $\begin{array}{l}\text { Nedunchezhiyan et al. } \\
\text { (2008) }\end{array}$ \\
\hline Foliar spraying with Calcium Nitrate & Rice & 194 & 327 & 550 & 928 & 69 & 0.86 & 1.38 & India & $\begin{array}{l}\text { Kundu and Sarkar } \\
\text { (2009) }\end{array}$ \\
\hline Foliar spraying with Potassium Chloride & Hybrid cotton & 317 & 454 & 899 & 1288 & 43 & 1.87 & 2.24 & India & $\begin{array}{l}\text { Aladakatti et al. } \\
\text { (2011) }\end{array}$ \\
\hline Phosphorus + VAM & Wheat & 159 & 268 & 451 & 760 & 68 & 1.55 & 1.86 & India & $\begin{array}{l}\text { Singh and Singh } \\
\text { (2008) }\end{array}$ \\
\hline Soil fertility amendments & Maize, legumes & 70 & 162 & 162 & 374 & 131 & 1.43 & 2.22 & Kenya & Okalebo et al. (2007) \\
\hline FYM + P fertilizer & Maize & 105 & 365 & 243 & 844 & 248 & 3.23 & 5.20 & Kenya & Odendo et al. (2007) \\
\hline Phosphorus, rotation & Maize, soybean, Mucuna & 122 & 478 & 282 & 1105 & 292 & 1.68 & 3.26 & Kenya & Kihara et al. (2010) \\
\hline Residue management & Maize & 469 & 525 & 1084 & 1214 & 12 & 1.86 & 3.57 & Kenya & Guto et al. (2011) \\
\hline Soil fertility management 'packages' & Maize, legumes & 121 & 391 & 280 & 904 & 224 & & & Kenya & Woomer (2007) \\
\hline Micro-dosing with fertilizer & Pearl millet & 83 & 152 & 164 & 300 & 83 & & & Niger & Tabo et al. (2007) \\
\hline Crop-livestock integration & Maize, groundnut, soybean & -33 & 413 & -55 & 690 & b & 0.92 & 1.72 & Nigeria & Franke et al. (2010) \\
\hline Fertilizer & Maize & 54 & 146 & 90 & 244 & 170 & 1.22 & 1.47 & Nigeria & Kolawole et al. (2007) \\
\hline Micro-dosing + seed priming & Sorghum & 50 & 206 & 99 & 406 & 312 & 1.82 & 3.27 & Sudan & $\begin{array}{l}\text { Aune and Ousmane } \\
\text { (2011) }\end{array}$ \\
\hline Micro-dosing + seed priming & Pearl millet & 45 & 90 & 89 & 178 & 100 & 1.65 & 2.17 & Sudan & $\begin{array}{l}\text { Aune and Ousmane } \\
\text { (2011) }\end{array}$ \\
\hline Micro-dosing + seed priming & Groundnut & 196 & 309 & 387 & 609 & 58 & & 9.06 & Sudan & $\begin{array}{l}\text { Ousmane and Aune } \\
\text { (2011) }\end{array}$ \\
\hline Micro-dosing + seed priming & Sesame & 215 & 329 & 424 & 649 & 53 & & 3.45 & Sudan & $\begin{array}{l}\text { Ousmane and Aune } \\
\text { (2011) }\end{array}$ \\
\hline Micro-dosing + seed priming & Cowpea & 69 & 117 & 136 & 231 & 70 & & 1.8 & Sudan & $\begin{array}{l}\text { Ousmane and Aune } \\
\text { (2011) }\end{array}$ \\
\hline Adding Azolla to the soil & Rice & 65 & 204 & 152 & 476 & 214 & 1.27 & 1.48 & Uganda & Kaizzi et al. (2007) \\
\hline Conventional versus Organic management & Cocoa- and vanilla-based systems ${ }^{a}$ & 290 & 522 & 676 & 1218 & 80 & 2.63 & 9.21 & Uganda & $\begin{array}{l}\text { Gibbon and Bolwig } \\
\text { (2007) }\end{array}$ \\
\hline Conventional versus Organic management & Pineapple-based systems ${ }^{\mathrm{a}}$ & 394 & 630 & 919 & 1470 & 60 & 1.65 & 24.07 & Uganda & $\begin{array}{l}\text { Gibbon and Bolwig } \\
\text { (2007) }\end{array}$ \\
\hline Conventional versus Organic management & Coffee-based systems ${ }^{\mathrm{a}}$ & 172 & 206 & 401 & 481 & 20 & 5.16 & 6.32 & Uganda & $\begin{array}{l}\text { Gibbon and Bolwig } \\
\text { (2007) }\end{array}$ \\
\hline \multicolumn{11}{|l|}{ d. Pest and disease control } \\
\hline Fungicide and phosphorus & Groundnut & 18 & 101 & 36 & 205 & 460 & 1.11 & 1.39 & Ghana & Naab et al. (2009) \\
\hline Improved weed control & Wheat & 208 & 398 & 590 & 1129 & 91 & 0.60 & 1.37 & India & Singh et al. (2010) \\
\hline Push-pull for stemborer and Striga & Maize, soybean, fodder ${ }^{c}$ & -28 & 283 & -65 & 654 & b & 0.79 & 3.16 & Kenya & De Groote et al. (2010) \\
\hline Integrated Striga Control & Sorghum, cowpea & -35 & 283 & -64 & 515 & b & -0.21 & 2.02 & Mali & $\begin{array}{l}\text { van Mourik, pers. } \\
\text { comm. (2011) }\end{array}$ \\
\hline Striga control & Maize & 84 & 274 & 140 & 458 & 226 & 1.37 & 3.19 & Nigeria & Aliyu et al. (2004) \\
\hline Integrated Striga Control & Cereals, legumes & -88 & 152 & -147 & 254 & b & 0.86 & 1.02 & Nigeria & Franke et al. (2006) \\
\hline \multicolumn{11}{|l|}{ e. Improved varieties } \\
\hline Improved versus local varieties, farmers' fields & Chickpea & 196 & 360 & 556 & 1021 & 84 & 4.28 & 5.6 & India & Shiyani et al. (2001) \\
\hline Improved versus local varieties & chickpea & 142 & 199 & 403 & 565 & 40 & 1.34 & 1.58 & India & Kiresur et al. (2010) \\
\hline $\begin{array}{l}\text { Improved versus local varieties (mean over all } \\
\text { crops in farmers' fields) }\end{array}$ & $\begin{array}{l}\text { Pearl millet, sorghum, mungbean, groundnut, wheat, } \\
\text { barley, mustard and chickpea }\end{array}$ & 208 & 283 & 590 & 803 & 36 & 2 & 2.58 & India & Mann et al. (2009) \\
\hline Improved variety, planting date, seed rate & Field bean (fodder) & -5 & 283 & -14 & 803 & b & 0.98 & 2.89 & India & Yusufali et al. (2007) \\
\hline Improved versus local varieties & Pigeonpea & -53 & 24 & -110 & 50 & b & & & Malawi & Simtowe et al. (2010) \\
\hline
\end{tabular}


Table 3

Average values for 'base' and 'improved' technology. Source: Table 2.

\begin{tabular}{lll}
\hline Variable & Base & Improved \\
\hline$N$ & 64 & 64 \\
Mean & 260.5 & 626.1 \\
Median & 185.5 & 557.5 \\
Std. deviation & 256.8 & 390.9 \\
Minimum & -164 & 50 \\
Maximum & 919 & 1734 \\
\hline
\end{tabular}

after planting coincides with the need to work off-farm in order to buy food. At peak periods, wage-labour can give higher returns than own farm production (Orr et al., 2009a). Third, in SSA, labour shortages are exacerbated by AIDS that reduces labour availability and the size of area cultivated (Niehof et al., 2010), not to mention the labour shortages experienced by households headed by women (Doss, 2001) that comprise up to one in four smallholder farms (Table 1). Finally, smallholders may derive more than half their income from non-farm sources (Table 1 ). From a livelihoods perspective, it is illogical to value family labour in agriculture at zero opportunity cost when households have alternative sources of income, however low-paid. Moreover, access to higher-paying nonfarm income is a key driver of graduation from poverty. The closer households are to graduation the more important this income becomes, and the higher the opportunity cost of family labour in agriculture. From the standpoint of poverty reduction, therefore, the opportunity cost of family labour in agriculture is the income earned in non-farm activities that offer a potential pathway from poverty.

'Income' refers to the monetized value of crop production, without implying that all crop production is sold for cash. The analysis is based on the proposition that the contribution from crop production to the income (in \$ per person per day) of each individual in a farming household depends on three factors: the total profitability of all cropping enterprises expressed as net returns in \$ per hectare per year; the amount of cropped land (in hectares per household); and the number of household members. This can be expressed as the amount of land required to produce enough income for each household member to just reach the poverty line:

$Y=(365 / X) \times n \times p l$

where $Y$ is the amount of land required (hectares); $X$ the net returns from all crop production ( $\$$ per hectare per year); $n$ the number of persons in the household; and $p l$ is the poverty line (\$ per day per capita).

The relationship between farm size and net returns from crop production was modelled using the values for farm size and crop income from six datasets from five countries in Table 1 (Jayne et al., 2001, Table 6; Simtowe et al., 2010). The data for crop income per ha was standardised to 2005 PPP values. Data for the mean farm size and farm size quartiles was pooled giving 30 observations.

The data showed large variations in the value of crop income per ha between countries. In all cases, crop income per ha declined with farm size. This is consistent with recent work by Larson et al. (2012) for Mozambique, Kenya, Malawi, Rwanda, and Zambia, which shows an inverse relationship between farm size and yield, reflecting variation in soil fertility, declining levels of labour, and sparse use of chemical fertilizer as farm size increases. However, the relationship between farm size and crop income per ha was non-linear for some countries and linear in others. An inverse function gave the best fit, but showed an implausibly steep drop in value of crop output per ha for farm below one ha. Determining the relationship between farm size and crop income per ha requires further work with additional household-level data and is beyond the scope of our paper. In view of these problems, we assumed a linear fit, using the slope derived from the pooled dataset. We assumed that the relationship between farm size and the value of crop income from improved technology would follow the same pattern. Using this simple framework, we computed the net household income from crops required to give an individual income of $\$ 1.25$ per person per day as a function of farm size for situations where all, $70 \%$ or $30 \%$ of household income was from crops. We also fitted this function to the value of crop income from improved technology, assuming that the median value of net crop income from improved technology ( $\$ 558 /$ ha/season at PPP 2005) represented crop income from a farm size of 0.5 ha.

This framework assumes that the main constraint on the potential of agricultural research to reduce poverty is the availability of land. We justify this by the paper's focus on poverty reduction. First, although labour and capital may also limit the adoption of improved technology, we show that, assuming these constraints can be overcome, the area of land required for improved crop production to lift households above the poverty line is still beyond the reach of many smallholders, particularly in India and eastern Africa. Second, poverty is concentrated in countries and regions where land is scarce. Using five of the datasets in Table 1, Jayne et al. (2003) show that, for farms below the median size, per capita income rises sharply with access to land. In summary, we are not constructing a farm model, but using a parametric budget to illustrate the binding nature of access to land on poverty reduction. Of course, this is simplistic, but it has the merit of concentrating minds on an issue - farm size - that is usually ignored in measuring benefits from agricultural research, which rarely estimates benefits at the household level.

\section{Results}

\subsection{What is the current level of net income from dryland crop production?}

Table 1 compares the results from household surveys and village-level studies. Since the surveys were made in different years, local currency units were converted to 2005 \$ PPP values. Results show wide variations in income per household and income from crop production. However, in six of the household surveys, mean household income was at or below $\$ 1500$ PPP per year. Mean income from crop production was below $\$ 1000$ PPP per year in six surveys. In seven of the 10 surveys income from crop production per adult worker was below $\$ 450$ per year, equivalent to an individual poverty line of $\$ 1.25$ per day. Since we do not know how much time workers actually spent on crop agriculture, this is not a true measure of labour productivity in agriculture, and the real figure would be even lower. The figures demonstrate that crop production does not generate enough income per year to allow adult workers to live above the poverty line, and certainly does not allow support of dependents at that minimal level. Results for Malawi and Ethiopia also show disparities between the national and local surveys. Thus, using local surveys to estimate the potential impact of new crop production technology on household income and on poverty at the national level (and vice versa) may give misleading results.

The national surveys reveal three other important features of smallholder agriculture. First, the small average size of farms. Of the six SSA countries, in only three countries (Burkina Faso, Kenya, and Zambia) was average farm size above two ha, and in four countries (Malawi, Ethiopia, Rwanda, and Mozambique), average farm size was smaller than in semi-arid India. Second, the relatively high share of net household income from crop production in SSA. In four countries (Ethiopia, Rwanda, Mozambique, and Zambia) crop 
production accounted for two-thirds or more of total household income while in the semi-arid villages in India the share was only one-third. Two countries in SSA - Malawi and Kenya - were close to this level, however. Third, the surveys show the importance of income from off-farm sources, contributing two-thirds of household income in India and up to one-third in some parts of SSA.

\subsection{How much can new technology raise net income from rainfed crop production?}

Table 2 presents the results of the literature survey, including outliers, showing levels of net income from rainfed cropping without improved technology, and the size of any likely increases following adoption of crop improvement and crop management interventions. Fig. 1 shows the ranking of net returns for both current and improved technology, not including outliers, and Table 3 presents summary statistics from Table 2 . Four conclusions may be drawn.

First, net returns, excluding outliers, for the 'base' cases were quite low and varied from negative values (where the enterprise made a loss) to around $\$ 900 /$ ha/season, while for improved technologies they ranged from about $\$ 120 /$ ha/season to around $\$ 1700 /$ ha/season. The median value of the seasonal net return from base technology was $\$ 186 /$ ha/season and from improved technology was $\$ 558 /$ ha/season. In absolute terms, the increase in median net returns from moving from current to improved crop production technology was $\$ 372 /$ ha/season. Second, in percentage terms the improved technologies were very effective. In only one case did an intervention fail to improve profitability by less than $20 \%$; in most cases the percentage increase was more than $100 \%$ and sometimes more than $1000 \%$. Third, even with new technology, net returns above $\$ 1000 /$ ha/season were rare and reflected unusual circumstances. For instance, one exception (Das et al., 2008) involved vegetable production after lowland rice in a very high rainfall area and net returns were calculated by assuming $100 \%$ sales - i.e. no spoilage of highly perishable produce and ready access to a market. Even apparent exceptions, such as returns from yams (Nedunchezhiyan et al., 2008; Nedunchezhiyan, 2010), fall within this range once the long duration of these crops (over 200 days, essentially equivalent to two seasons) is taken into account. Fourth, new technology gave an acceptable return on investment $(B C R=2)$. Information on benefit-cost ratios (BCRs) was available for 49 of the interventions in Table 2. The median BCR for base and improved technologies was 1.62 and 2.24, respectively. For the base technologies, only $18 \%$ had BCRs of 2 or over, while the share for improved technologies was 69\%. Transforming base and improved BCRs to natural logarithms, a paired $t$-test showed that improved technology significantly improved returns to investment in crop production $(t$-value $=-6.715$, significant at $1 \%$ level).

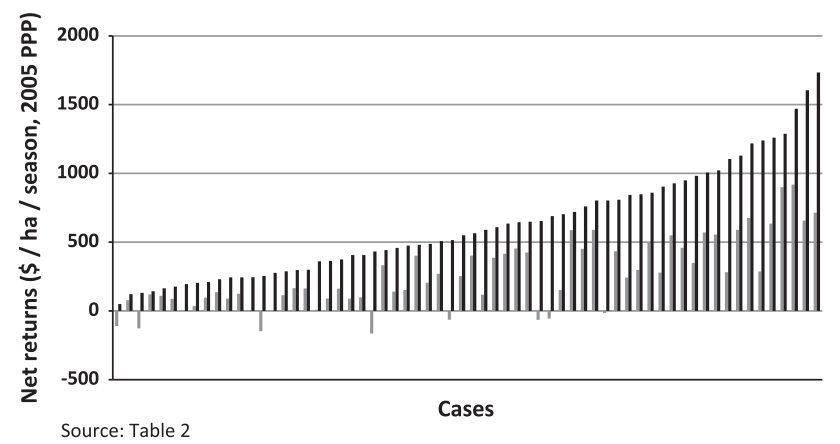

Fig. 1. Net returns from base (light bars) and improved (dark bars) technologies $(n=64)$.

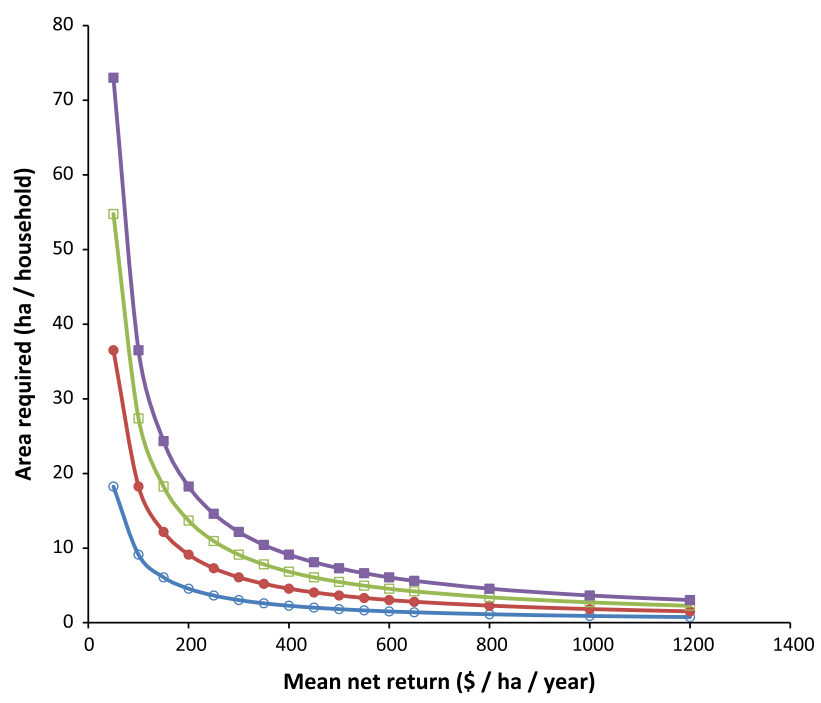

Fig. 2. Land required to produce an individual income of $\$ 1.25$ per person per day, as a function of net returns from crop production, for a range of household sizes $(n)$ : open circles, $n=2$; closed circles, $n=4$; open squares, $n=6$; closed squares, $n=8$. Values calculated using Eq. (1).

\subsection{What impact will this gain in income have on poverty at the household level?}

Fig. 2 shows the relation between land area, net returns and household size represented by Eq. (1) for an IPL of $\$ 1.25 /$ person/ day. This clearly shows the effect of low returns and large household size on the area of land required to reach the poverty line. For example, with a net income of $\$ 558 /$ ha/year from crop production (the median value for improved technology), a family of two requires 1.68 ha to reach the IPL, compared to 6.73 ha for a family of eight. Fig. 2 assumes that a given net return stays constant over the entire area of land cultivated. Keeping the same assumption, Fig. 3 shows how the area of land required to reach the IPL changes if we vary the share of household income derived from crop production. If we consider a representative household with five members who can gain a net return of $\$ 558 /$ ha/year on all of their land, the area required to reach the IPL when all income comes from crop production is 4.15 ha. If only $70 \%$ of household income is from

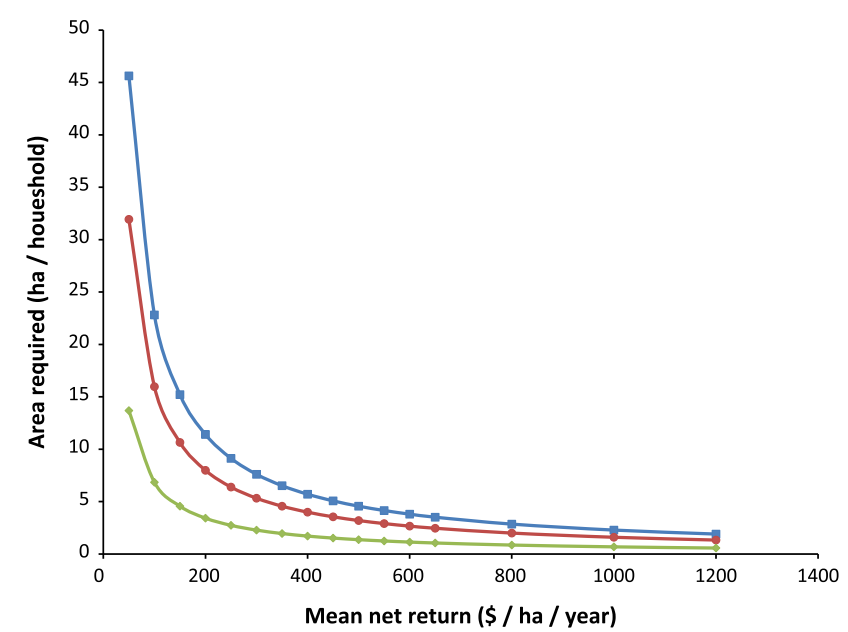

Fig. 3. Land required to produce an individual income of $\$ 1.25$ per person per day, as a function of net returns from crop production, for: $100 \%$ of household income from crop production (squares); $70 \%$ from crop production (circles); $30 \%$ of income from crop production (diamonds). Values calculated using Eq. 1. 
crops the area required falls to 2.9 ha and for a case where only $30 \%$ of income is from crops the area required is only 1.24 ha (Fig. 3). These smaller land areas are well within the range of farm sizes operated in SSA and India (Table 1; Nagayets, 2005; Bélières et al., 2013).

However, we know that smallholders find it difficult to maintain the same net return per hectare from a large area that they can achieve on a small area, and expect the net return from crop production to decline as farm size increases. Fig. 4 illustrates this decline based on the linear trend derived from the pooled dataset for five countries in Table 1. Assuming one cropping season per year, the net return from improved technology falls from $\$ 558$ / ha/season on a farm of 0.5 ha to only $\$ 415 /$ ha/season on a farm of 4 ha. Fig. 4 also shows that the effect of farm size on household income from crops after adopting the median improved technology is slightly non-linear. Table 4 shows the numerical values derived from Fig. 4 for a range of farm sizes and share of total household income from agriculture, providing insights into the interaction between profitability, the degree of reliance of households on income from crop production, and farm size. With declining net returns per hectare as farm size increases, and assuming that all household income comes from crop production, a five-person household with 1 ha of land would derive a net annual income from adoption of the median improved technology of only $\$ 539$ (a Personal Daily Income [PDI] of only 29 US cents/day), rising to \$984 (a PDI of 54 cents) from 2 ha and $\$ 1660$ (PDI = 91 cents) from 4 ha (Table 4). Where income from crops is less important, the net return required also falls. In Table 4 the net returns required to reach the IPL only fall below the median value of $\$ 558 /$ ha when cropping income is a small proportion of total income or for larger farms. Where crop income is relatively important, the likelihood of reaching the IPL, even after adopting improved technologies, is small given the land areas operated by most smallholder households.

It is important to be clear on what is meant by a net return value. The relationship defined in Eq. (1) and shown in Figs. 2 and 3 uses the term in the sense that the value is the mean over all the land area considered and is thus relevant for whole-farm situations. In contrast, values from the literature shown in Table 2 and Fig. 1 and used to calculate the values in Table 3 were mostly derived from trials implemented on small pieces of land. Although they are expressed on a per hectare basis, these values will decline as the area on which they are implemented by farmers increases, as shown in Fig. 4 and Table 4. This has important implications for the practical value of improved technologies because the estimates of net returns by researchers based on small plot studies are overestimates when the technologies are adopted on larger areas (Fig. 4).

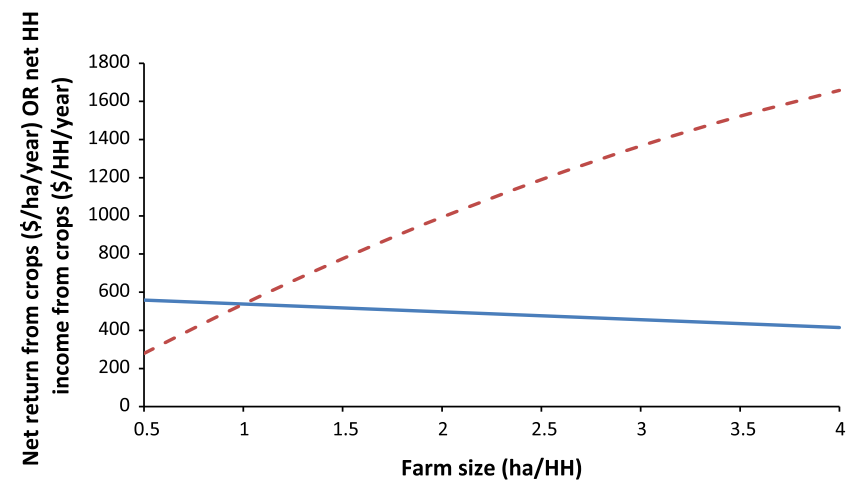

Fig. 4. Relation between net return from crops ( $\$ /$ ha/year, solid line), net household income from crops $(\$ / \mathrm{HH} /$ year, broken line) and farm size (cultivated area) assuming a value of $\$ 558 /$ ha/year (the median value for improved technologies from Table 3 ) evaluated on 0.5 ha.
These results are illustrative only. Actual values for the required farm size and net income from crop production required to reach an income of $\$ 1.25$ per day will vary. In addition, where two seasons per year are possible, e.g. through favourable rainfall patterns or by using irrigation, this will approximately halve the farm size and/or net income per season from crop production required to reach the poverty line.

\section{Discussion}

ICRISAT's strategy for the tropical drylands is based on the premise that 'poor people can grow their way out of poverty' (ICRISAT, 2010). What are the implications of our results for this strategy?

Disappointing research impacts have been blamed on the failure to develop innovations that are both profitable and low-risk (Anderson, 1992). There is some truth in this argument. Our literature survey identified a wide range of interventions covering almost every conceivable aspect of crop production and, as we have seen, $31 \%$ of interventions had CBRs of less than 2 , which is normally considered the minimum required for adoption. Even where the CBR is above 2, it does not capture the risk of adoption or the scale of the investment required, which may make interventions inappropriate for poorer smallholders. Although some of the technologies listed in Table 2 were tested over multiple years, the average period of testing was only two seasons, and none of the publications explicitly estimated risk. Nevertheless, the results confirm the potential of new technology to raise net income from crop production. In absolute terms, the median value for net income from rainfed crop production with 'base' technology is $\$ 186 /$ ha/season. New technology has the potential to raise this to about $\$ 558 /$ ha/season, an increase of $200 \%$. At the margin, this is a significant percentage gain in income. Subsidies that reduce input costs can further raise the profitability of new technology, although the increase in profitability required for improved technology to lift smallholders above the poverty line is clearly unaffordable for most developing countries. However, higher income is not the only benefit from improved technology. Improved varieties of sorghum and millet can also reduce vulnerability to drought by stabilizing yield (Deb and Bantilan, 2003). In addition, improved management practices for rainfed crops can more than compensate for the negative effects of climate change on yield, although their effect on net returns is less certain (Cooper et al., 2009). Thus, new technology can not only raise the absolute level of income from crop production but also reduce the variability of that income, although data on the variability of particular technologies is scarce.

There are two reasons for the limited impact of new technology on poverty. One is the agrarian structure. As we have seen, $80 \%$ of farms in developing countries (including 22 million farms in SSA) cultivate less than 2 ha. Rapid population growth and land fragmentation will reduce average farm size still further. As a result, in some countries and regions in SSA the agrarian structure will increasingly come to resemble that in Malawi where 'most resource-poor smallholders, even with new technologies or the ability to produce higher-value crops, will not be able to generate enough income from on-farm agricultural production to escape poverty' (Alwang and Seigel, 1999). The second reason is the low value of net returns from rainfed crop production. Table 2 suggests a de facto limit to net returns from rainfed crop production of around $\$ 1700 /$ ha/season. The median value of $\$ 558 /$ ha/season is similar to or sometimes higher than that found in developed countries. In the United States, for example, the net returns from maize, sorghum, wheat, barley, soybean and cotton have been in the range $\$ 40 /$ ha to $\$ 210 /$ ha for long periods (USDA, 2009). Similarly, in South Australia in 2009, gross margins for 11 crops in the most 
Table 4

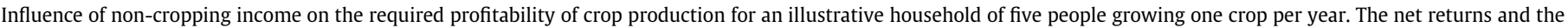

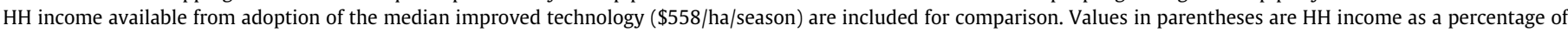
the income equivalent to the IPL for five people $(\$ 2281 / \mathrm{HH})$.

\begin{tabular}{|c|c|c|c|c|c|}
\hline \multirow[t]{2}{*}{ Farm size (ha) } & \multicolumn{3}{|c|}{ Net return required $(\$ /$ ha $)$ for $\$ 1.25 /$ person/day } & \multirow{2}{*}{$\begin{array}{l}\text { Net return from median } \\
\text { improved technology, } \$ / \text { ha }\end{array}$} & \multirow{2}{*}{$\begin{array}{l}\text { Net income from median } \\
\text { improved technology, } \$ / \mathrm{HH}\end{array}$} \\
\hline & $100 \%$ from crops & $70 \%$ from crops & $30 \%$ from crops & & \\
\hline 0.5 & 4562 & 3193 & 1369 & 558 & $279(12 \%)$ \\
\hline 1 & 2281 & 1597 & 684 & 539 & $539(24 \%)$ \\
\hline 2 & 1141 & 798 & 342 & 492 & $984(43 \%)$ \\
\hline 3 & 760 & 532 & 228 & 455 & $1365(60 \%)$ \\
\hline 4 & 570 & 399 & 171 & 415 & $1660(73 \%)$ \\
\hline
\end{tabular}

Note: Italicised areas denote values of net returns below the median value from improved technology ( $\$ 558 / \mathrm{ha} / \mathrm{season})$.

productive areas with the highest rainfall ranged from $\$ 197 /$ ha (for triticale) to $\$ 751 /$ ha (for grain vetch) with a mean of $\$ 361 /$ ha (Rural Solutions SA, 2010). Where farm size averages 200 ha or more as in the United States such returns per farm are highly lucrative but in developing countries where most farms are 2 ha or less they mean small incomes from crop production.

Let us be clear. We are not disputing the importance of agriculture for poverty reduction. There is clear evidence of a link between productivity growth and the share of the population living in poverty. A $1 \%$ increase in crop yields reduces headcount poverty by $0.91 \%$ worldwide and by $0.96 \%$ in Africa (Lin et al., 2001). Similarly, at the micro-level there is evidence that crop production is a pathway from poverty. In Kenya, for example, a national survey revealed that of the sampled households that moved out of poverty between 1990 and 2005, half attributed their success to investment in agriculture (Kristjanson et al., 2010). Similarly, 70\% of households that moved out of poverty in Uganda between 1980 and 2004 stated that the main driver of ascent was agriculture (Krishna et al., 2006). This may seem to contradict our earlier results showing that income from new technology was not enough to lift a 2 ha farm above the poverty line. However, what matters is the process by which smallholders move out of poverty. If households graduate from poverty by acquiring more land, then crop production may not be a viable pathway for farms that stay small. Alternatively, if small farms move out of poverty through intensification or commercialisation, this suggests that crop production can generate the level of income required to make it a viable pathway from poverty.

What does the evidence show? In Kenya, panel surveys showed that between 1997 and 2007, "households moving out of poverty more than doubled their landholding size and cultivated 70\% more land in 2007 than in 1997' (Muyanga et al., 2010). In Mozambique between 2002 and 2005, smallholders who moved out of poverty increased their land cultivated by $10 \%$ (Cunguara, 2008). In Zambia, households moving out of poverty had increased their landholding from 5 ha at inheritance to 23 ha (Banda et al., 2011). Generally, households give more than one reason for moving out of poverty, which makes it difficult to identify a single pathway. Bigger farm size usually went hand in hand with crop diversification and commercialisation. Of the reasons given for graduation from poverty in Kenya, only $23 \%$ of households cited increased land under cultivation, compared to $49 \%$ who cited crop diversification or commercialisation. In the zone with low potential for crop production, one-half of the households moving out of poverty attributed this to crop diversification away from maize to higher-value crops (Kristjanson et al., 2010). Not all forms of commercialisation are necessarily pathways from poverty. Smallholder dairying in Kenya gave annual net returns that ranged from \$889 PPP per household on farms averaging 1.2 ha and without access to communal grazing to \$1348 PPP per household where farms averaged 3.6 ha and with access to communal land (Ngigi, 2005). But investment in cattle is usually seen as a sign that households have already emerged from poverty. Smallholder dairying is more of a strategy for staying above the poverty line than for climbing out of poverty (Krishna et al., 2004; Burke et al., 2007). Finally, the evidence confirms the importance of non-farm income. In Kenya, $80 \%$ of households that moved out of poverty also attributed graduation to business and non-farm employment (Kristjanson et al., 2010). This exemplifies the classic cycle in which non-farm income is invested in agriculture while agriculture generates income for non-farm investment (Ellis and Freeman, 2004).

These results suggest that there are three scenarios under which crop production may function as a direct pathway from poverty. Scenario one (Extensification) is where smallholders are able to increase farm size, allowing them to overcome the low net return from crop production by expanding the area planted. This is the same as contracting the $y$-axis in Fig. 2 or expanding the $x$-axis in Fig. 3. The second scenario (Commercialisation) is where smallholders are able to diversify and commercialize crop production in response to market demand, allowing them to increase the net value of crop production without the need to acquire additional land. This is equivalent to moving along the $x$-axis in Fig. 2 and coming down the $y$-axis in Fig. 3. Scenario three (Income Diversification) is where smallholders can increase the share of household income from non-farm sources. Some of this income may be re-invested in crop production to raise yields and improve household food security. This scenario is represented in Fig. 3. Of these three scenarios, one and three have the greatest potential as a pathway from poverty. Scenario two - crop diversification and commercialisation - requires a high level of net income from crop production. Our literature survey showed, however, that net income from high-value crops did not exceed \$700/ha/season and that this was insufficient to lift a typical small farm out of poverty. In practice, small farmers attribute graduation from poverty to a combination of all three possible strategies.

These scenarios have different implications for welfare. Expanding farm size and intensification may not be feasible strategies for poorer smallholders. Bigger farm size may require investment in animal traction. In ICRISAT's West African villages between 1985 and 2000 the area cultivated per capita rose by 75\%, from 0.8 to $1.6 \mathrm{ha}$, a change due to the increased use of animal draught power (Ndjeunga and Savadogo, 2002). Similarly, crop diversification or commercialisation may be constrained by a shortage of labour. Although small farms in southern Malawi have sufficient labour for timely crop production, lack of access to credit and cash shortages make it rational for households to delay planting in order to earn off-farm income (Alwang and Seigel, 1999). Where land is still abundant, increasing farm size has no social cost, but where the land frontier has already been reached, the consequences may be different. If farms grow bigger at the expense of other small farms, then graduation through crop production may actually create poverty rather than reduce it. This highlights the need to combine crop 
production with non-farm income that does not rely on increasingly limited land.

In summary, the evidence that crop production is a direct pathway from poverty is weak. The additional income from new technology, even if adopted (and the increased investment and low returns relative to other enterprises may negatively influence adoption decisions), is not sufficient to lift a typical smallholder farm above the poverty line. True, graduation from poverty is not a one-off event based on the income from crop production for a single year, but a process. Some of this additional income can be invested and generate further income that will allow households to move out of poverty over time. However, this is unlikely unless small farms can also acquire more land, access new markets, or find higher-paying non-farm employment. Smallholders will still gain from new technology, but the primary benefits will be improved household food security, reduced risk, and the capacity to invest in assets that will generate additional income. A recent study of households graduating from poverty in Bangladesh shows the importance of improving household food security as a first step from poverty (Orr et al., 2009b). Similarly, while the Millennium Village programme in Kenya increased per capita income in 2005 PPP values by only $\$ 29$ per year (a PDI of eight US cents), there was a significant impact on household food security, with a $78 \%$ increase in the quantity of maize produced and consumed by the household (Wanjala and Muradian, 2013). However, the impact of new technology on household food security has not received the same attention as the impact on poverty.

Agriculture's main impact on poverty may be indirect. Determining the relative contribution of direct and indirect benefits is complex, since they may affect rural households simultaneously. This complexity is mirrored in the historical experience of the Green Revolution in Bangladesh, based on evidence from a panel survey between 1987 and 2000. Households that graduated from poverty did benefit directly from new rice technology: they bought land, trebled the area they planted to improved varieties, and doubled their income from rice. But this was not enough to lift them above the poverty line. The main driver of graduation was income from non-farm sources, which rose from $36 \%$ to $57 \%$ of household income (Sen, 2003). However, the Green Revolution had substantial indirect impacts. As a result of the fall in the real price of rice, agricultural wages rose from $2.7 \mathrm{~kg}$ to $5.1 \mathrm{~kg}$ of rice per day (Sen, 2003). Because the poor spend one-third of their income on rice, this was a major reason for the decline in poverty in Bangladesh since the mid-1980s (Hossain, 2010). At the global level, the Green Revolution seems to have followed a similar pattern. Had there been no Green Revolution, world rice prices in 2000 would have been at least $80 \%$ and potentially $124 \%$ higher than they actually were (Evenson and Rosegrant, 2003). Thus, the primary impact of the Green Revolution on poverty in Asia was to reduce the share of household income spent on food by effectively halving rice prices.

Indirect effects may be less important in Africa, however. General equilibrium modelling for an 'archetype' African economy suggests that a $10 \%$ increase in food crop productivity would increase income on small and medium farms by $3.9 \%$, of which only $28 \%$ would be indirect, compared to direct effects of $72 \%$ (de Janvry and Sadoulet, 2002). This is because the majority of the rural poor in Africa are smallholders, not rural households without land or where most income is earned off-farm. However, most smallholders (55\%) are net food buyers who would benefit from lower food prices (Larsson, 2005). Moreover, growing landlessness and rapid urbanisation will increase the share of indirect benefits from new technology. At present, however, agriculture's ability to reduce poverty in Africa depends primarily on the direct benefits to smallholders. Our results suggest that, although new technology for crop production raises household income, the direct benefits are too small to lift most smallholders above the poverty line.

\section{Conclusions}

“Development's buzzwords gain their purchase and power through their vague and euphemistic qualities, their capacity to embrace a multitude of possible meanings... The work that these words do for development is to place the sanctity of its goals beyond reproach" (Cornwall, 2007).

What exactly do we mean when we say that agriculture is a pathway from poverty? Are we suggesting new technology is so profitable that it alone can provide every member of a poor farm household with more than $\$ 1.25$ per day? Alternatively, are we suggesting that agriculture alone is not enough for farmers to graduate from poverty, but that investment in agriculture is an essential precondition? For which farmers? Which crops? In which environments? Like other development buzzwords, the rhetoric of poverty reduction is rich in imprecision.

The evidence suggests that there are two situations where crop production can be a pathway from poverty. The first is where smallholders can acquire land to increase farm size. This is still possible is some African countries but less feasible in South Asia and in many parts of eastern Africa where the land frontier has already been reached and extensification may exacerbate poverty. The second is where new markets stimulate demand for crop diversification towards higher-value crops or commercialisation. For small farms unable to increase farm size or without higher prices through access to better-functioning markets, however, the evidence suggests that crop production is not a viable pathway from poverty. The returns from improved technology are too low and farms are too small to produce the income required to lift a typical smallholder family above the poverty line. For such farmers, the direct benefit from new technology will be to provide a stable foundation of food security that, if not accompanied by increased risk, provides a stepping stone from poverty but not a complete pathway.

Agriculture's contribution to poverty reduction is not in dispute but this contribution needs to be more carefully specified, taking account of small farm size and the low agronomic potential of rainfed agriculture. These suggest the need to modify overly optimistic views about the ability of crop production in the drylands to reduce poverty. For most small farms in the drylands, improved technology for crop production is not and cannot be a pathway from poverty. This conclusion makes uncomfortable reading but may challenge others to re-think the potential of agricultural research to reduce poverty in the drylands.

\section{Acknowledgements}

We thank Todd Benson, Uttar Kumar Deb, Thom Jayne, V. Kiresur, and F. Simtowe for information on the sources in Table 1, Ben Munyua for computational assistance, Phil Dobie and A. Amerender Reddy for literature, and Dave Hoisington, Peter Craufurd, and two reviewers for useful comments. The views expressed in this paper are those of the authors and should not be attributed to the institution with which they are affiliated.

\section{References}

Ajayi, O.C., Akinnifesi, F.K., Sileshi, G., Kanjipite, W., 2009. Labour inputs and financial profitability of conventional and agroforestry-based soil fertility management practices in Zambia. Agrekon 48, 276-292.

Aladakatti, Y.R., Hallikeri, S.S., Nandagavi, R.A., Naveen, N.E., Hugar, A.Y., Blaise, D., 2011. Yield and fiber qualities of hybrid cotton (Gossypiumhirsutum) as 
influenced by soil and foliar application of potassium. Karnataka J. Agric. Sci. 24 (2), 133-136.

Aliyu, L., Lagoke, S.T.O., Carsky, R.J., Kling, J., Omotayo, O., Shebayan, J.Y., 2004. Technical and economic evaluation of some Striga control packages in maize in the Nigerian Guinea Savanna. Crop Prot. 23, 65-69.

Alwang, J., Seigel, P.B., 1999. Labor shortages on small landholdings in Malawi: implications for policy reforms. World Dev. 27 (8), 1461-1475.

Anderson, J.R., 1992. Difficulties in African agricultural systems enhancement? Ten hypotheses. Agric. Syst. 38, 387-409.

Asfaw, S., Shiferaw, B., Simtowe, F., Muricho, G., Ferede, S., 2010. Socio-economic assessment of legume production, farmer technology choice, market linkages, institutions and poverty in rural Ethiopia. Institutions, Markets, Policies and Impacts Research Report No. 3, International Crops Research Institute for the Semi-Arid Tropics, Patancheru.

Aune, J.B., Ousmane, A., 2011. Effect of seed priming and micro-dosing of fertilizer on sorghum and pearl millet in western Sudan. Expl. Agric. 47 (3), 419-430.

Badiani, R., Dercon, S., Krishnan, P., Rao, K.P.C., 2007. Changes in Living Standards in Villages in India 1975-2004: Revisiting the ICRISAT village level studies. Chronic Poverty Research Centre, Working Paper 85.

Banda, D. J., Hamukwala, P., Haggblade, S., Chapoto, A., 2011. Dynamic Pathways Into and Out of Poverty: a Case of Smallholder Farmers in Zambia. Food Security Research Project, Zambia. Working Paper No. 56.

Baudron, F., Andersson, J.A., Corbeels, M., Giller, K.E., 2012. Failing to yield? Ploughs, conservation agriculture and the problem of agricultural intensification: an example from the Zambezi Valley. Zimbabwe. J. Dev. Stud. 48 (3), 393-412.

Beintema, N.K., Stads, G.-J., 2008. Measuring Agricultural Research Investments. A Global Picture. Agricultural Science \& Technology Indicators. Background Note. October

Bélières, J.-F., Bonnal, P., Bosc, P.-M., Losch, B., Marzin, J., Sourisseau, J.-M., 2013. Les Agricultures Familiales du Monde. Définitions, Contributions et Politiques Publiques. Montpellier, Paris. CIRAD, AFD.

Bryceson, D.F., 2002. The scramble in Africa: reorienting rural livelihoods. World Dev. 30 (5), 725-739.

Burke, W.J., Jayne, T.S., Freeman, H.A., Kristjanson, P., 2007. Factors Associated with Farm Households' Movement Into and Out of Poverty in Kenya: The Rising Importance of Livestock. Michigan State University Development Working Paper No. 90.

Centro Internacional de Mejoramiento de Maíz y Trigo (CIMMYT), 1988. From Agronomic Data to Farmer Recommendations: An Economics Training Manual. CIMMYT, Mexico, DF.

Chambers, R., 1983. Rural Development: Putting the Last First. Intermediate Technology Publications, London.

Collier, P., Dercon, S., 2009. African Agriculture in 50 Years: Smallholders in a Rapidly Changing World? How to Feed the World in 2050. High Level Expert Forum, Rome, 12-13 October. Food and Agriculture Organisation of the United Nations, Rome.

Consultative Group for International Agricultural Research (CGIAR), 2005. Agricultural Research Matters: Achieving the Millennium Development Goals, CGIAR, Washington, DC.

Cooper, P., Rao, K.P.C., Singh, P., Dimes, J., Traore, P.S., Rao, K., Dixit, P., Twomlow, S.J., 2009. Farming with current and future climate risk: advancing a 'Hypothesis of Hope' for rainfed agriculture in the semi-arid tropics. J. SAT Agric. Res. 7, 1-19.

Cornwall, A., 2007. Buzzwords and fuzzwords: deconstructing development discourse. Dev. Pract. 17 (4-5), 471-484.

Cunguara, B.A., 2008. Pathways out of Poverty in Rural Mozambique. M.Sc. Thesis, Michigan State University.

Das, A., Patel, D.P., Munda, G.C., Hazarika, U.K., Bordoloi, J., 2008. Nutrient recycling potential in rice-vegetable cropping sequences under in situ residue management at mid-altitude subtropical Meghalaya. Nutr. Cycl. Agroecosyst. $82,251-258$.

De Groote, H., Vanlauwe, B., Rutto, E., Odhiambo, G.D., Kanampiu, F., Khan, Z.R., 2010. Economic analysis of different options in integrated pest and soil fertility management in maize systems of Western Kenya. Agric. Econ. 41, 471-482.

De Janvry, A., Sadoulet, E., 2002. World poverty and the role of agricultural technology: direct and indirect effects. J. Dev. Studs. 38 (4), 1-26.

Deb, U.K., Bantilan, M.C.S., 2003. Impacts of genetic improvement in Sorghum. In: Evenson, R.E., Gollin, D. (Eds.), Crop Variety Improvement and Its Effect on Productivity. The Impact of International Agricultural Research. CABI Publishing, Wallingford, pp. 183-214.

Deshmukh, M.R., Duhoon, S.S., 2008. Effect of organic inputs on sesame (Sesamum indicum L.) under rainfed situation in Kymore Plateau Zone of Madhya Pradesh (India). J. Maharashtra Agric. Univ. 33 (3), 323-324.

Dogan, R., Goksoy, T.A., Yagdi, K., Turan, M.Z., 2008. Comparison of the effects of different crop rotation systems on winter wheat and sunflower under rain-fed conditions. Afr. J. Biotechnol. 7 (22), 4076-4082.

Doss, C., 2001. Designing agricultural technology for African women farmers: lessons from 25 years of experience. World Dev. 29 (12), 2075-2092.

Ellis, F., 1993. Peasant Economics: Farm Households and Agrarian Development, second ed. Cambridge University Press, Cambridge.

Ellis, F., 2005. Small farms, livelihood diversification and rural-urban transitions: Strategic issues in Sub-Saharan Africa. Paper presented at the research workshop on 'The Future of Small Farms', Wye College, Kent, UK, 26-29 June, 2005. International Food Policy Research Institute and Overseas Development Institute.

Ellis, F., Biggs, S., 2001. Evolving themes in rural development 1950s-2000s. Dev. Policy Rev. 19 (4), 437-448.
Ellis, F., Freeman, H.A., 2004. Rural livelihoods and poverty reduction strategies in four African countries. J. Dev. Stud. 40 (4), 1-30.

Evenson, R.E., Rosegrant, M., 2003. The economic consequences of crop genetic improvement programmes. In: Evenson, R.E., Gollin, D. (Eds.), Crop Variety Improvement and Its Effect on Productivity. The Impact of International Agricultural Research. CABI Publishing, Wallingford, pp. 473-497.

Food and Agriculture Organisation (FAO), 2000. Land Resource Potential and Constraints at Regional and Country Levels. World Soil Resources Report. No. 90. Food and Agriculture Organisation of the United Nations, Rome.

Franke, A.C., Ellis-Jones, J., Tarawali, G., Schulz, S., Hussaini, M.A., Kureh, I., White, R. Chikoye, D., Douthwaite, B., Oyewole, B.D., Olanrewaju, A.S., 2006. Evaluating and scaling-up integrated Striga hermonthica control technologies among farmers in northern Nigeria. Crop Prot. 25, 868-878.

Franke, A.C., Berkhout, E.D., Iwuafor, E.N.O., Nziguheba, G., Dercon, G., Vandeplas, I. Diels, J., 2010. Does crop-livestock integration lead to improved crop production in the savanna of West Africa? Expl. Agric. 46 (4), 439-455.

Gibbon, P., Bolwig, S., 2007. The Economics of Certified Organic Farming in Tropica Africa. Working Paper No 2007/3, Danish Institute for International Studies, Copenhagen.

Gichangi, E.M., Njiru, E.N., Itabari, J.K., Wambua, J.M., Maina, J.N., Karuku, A., 2007 Assessment of improved soil fertility and water harvesting technologies through community based on-farm trials in the ASALs of Kenya. In: Bationo, A., Waswa, B., Kihara, J., Kimetu, J. (Eds.), Advances in Integrated Soil Fertility Management in Sub-Saharan Africa: Challenges and Opportunities. Springer, Netherlands, pp. 759-765.

Gogoi, B., Barua, N.G., Baruah, T.C., 2010. Effect of integrated nutrient management on growth, yield of crops and availability of nutrients in Inceptisol under rainfed rice (Oryza sativa) - niger (Guizotia abyssinica) sequence of Asom. Indian J. Agric Sci. 80 (9), 824-828.

Government of Malawi (GOM), 2000. Integrated Household Survey 1997-98. Draft Report. Statistical Abstract. June. National Statistical Office, Zomba.

Guto, S.N., Pypers, P., Vanlauwe, B., de Ridder, N., Giller, K.E., 2011. Socio-ecological niches for minimum tillage and crop-residue retention in continuous maize cropping systems in smallholder farms of Central Kenya. Agron. J. 103 (3), 1-11.

Haggblade, S., Tembo, G., Donovan, C., 2004. Household Level Financial Incentives to Adoption of Conservation Agricultural Technologies in Africa. Working Paper No. 9, Food Security Research Project, Lusaka, Zambia.

Harvest Choice, 2011. <http://harvestchoice.org/households/market_access>

Hazell, P., Poulton, C., Wiggins, S., Dorward, D., 2010. The future of small farms: trajectories and policy priorities. World Dev. 38 (10), 1349-1361.

Hossain, M., 2010. Shallow tubewells and Boro rice in Bangladesh. In: Speilman, D.J. Pandya-Lorch, R. (Eds.), Proven Successes in Agricultural Development. A Technological Compendium to Millions Fed. International Food Policy Research Institute, Washington, DC, pp. 243-269.

International Crops Research Institute for the Semi-Arid Tropics (ICRISAT), 2010 ICRISAT Strategic Plan to 2020. Inclusive Market-Oriented Development for Smallholder Farmers in the Tropical Drylands. ICRISAT, Patancheru.

International Crops Research Institute for the Semi-Arid Tropics (ICRISAT) and International Centre for Agricultural Research in the Dry Areas (ICARDA), 2012 Dryland Cereals. A Global Alliance for Improving Food Security, Nutrition and Economic Growth for the World's Most Vulnerable Poor. A CGIAR Research Program submitted by ICRISAT and ICARDA to the CGIA Consortium Board. 15 August.

Islam, N., 2011. Foreign Aid to Agriculture: Review of Facts and Analysis. Discussion Paper No. 01053. International Food Policy Research Institute, Washington, DC.

Jayne, T.S., Yamano, T., Weber, M.T., Tschirley, D., Benfica, R., Chapoto, A., Zulu, B. 2001. Smallholder income and land distribution in Africa: implications for poverty reduction strategies. Draft Paper.

Jayne, T.S., Yamano, T., Weber, M.T., Tschirley, D., Benfica, R., Chapoto, A., Zulu, B., 2003. Smallholder income and land distribution in Africa: implications for poverty reduction strategies. Food Policy 28 (3), 253-275.

Jayne, T.S., Mather, D., Mghenyi, E., 2010. Principal challenges confronting smallholder agriculture in Sub-Saharan Africa. World Dev. 38 (10), 1384-1398.

Kabwe, S., Donovan, C., Samazaka, D., 2007. Assessment of the farm level financial profitability of the Magoye ripper in maize and cotton production in Southern and Eastern Provinces. Working Paper No. 23, Food Security Research Project, Lusaka, Zambia.

Kaizzi, C.K., Ssali, H., Nansamba, A., Vlek, P.L.G., 2007. The potential benefits of Azolla, velvet bean (Mucunapruriens var. utilis) and $\mathrm{N}$ fertilizers in rice production under contrasting systems in eastern Uganda. In: Bationo, A. Waswa, B., Kihara, J., Kimetu, J. (Eds.), Advances in Integrated Soil Fertility Management in Sub-Saharan Africa: Challenges and Opportunities. Springer, Netherlands, pp. 423-433.

Kihara, J., Vanlauwe, B., Waswa, B., Kimetu, J.M., Chianu, J., Bationo, A., 2010 Strategic phosphorus application in legume-cereal rotations increases land productivity and profitability in Western Kenya. Expl. Agric. 46 (1), 35-52.

Kihara, J., Bationo, A., Waswa, B., Kimetu, J.M., Vanlauwe, B., Okeyo, J., Mukalama, J. Martius, C., 2012. Effect of reduced tillage and mineral fertilizer application on maize and soybean productivity. Expl. Agric. 48 (2), 159-175.

Kiresur, V.R., Bantilan, M.C.S., Parthasarathy, R.P., Rao, G.D.N., Padmaja, R. Anupama, K.V., Suhasini, K., Kulkarni, G.N., 2010. Chickpea breeding and seed delivery efforts to enhance the impact on the livelihoods of the poor in droughtprone areas of South Asia - insights from baseline studies. Summary Report. International Crops Research Institute for the Semi-Arid Tropics, Patancheru.

Kolawole, G.O., Diels, J., Manyong, V.M., Ugbabe, O., Wallays, K., Dercon, G., Iwuafor E.N.O., Falaki, A.M., Merckx, R., Deckers, J., Tollens, E., Vanlauwe, B., Sanginga, N., 
2007. Balanced nutrient management system technologies in the northern Guinea Savannah of Nigeria: validation and perspective. In: Bationo, A., Waswa, B., Kihara, J., Kimetu, J. (Eds.), Advances in Integrated Soil Fertility Management in Sub-Saharan Africa: Challenges and Opportunities. Springer, Netherlands, pp. 669-678.

Krishna, A., Shariff, A., 2011. The irrelevance of national strategies? Rural poverty dynamics in states and regions of India, 1993-2005. World Dev. 39 (4), 533549.

Krishna, A., Kristjanson, P., Radeny, M., Nindo, W., 2004. Escaping poverty and becoming poor in 20 Kenyan villages. J. Human Dev. 5 (2), 211-226.

Krishna, A., Lumonya, D., Markiewicz, M., Mugumya, F., Kafuko, A., Wegoye, J., 2006. Escaping poverty and becoming poor in 36 villages of Central and Western Uganda. J. Dev. Stud. 42 (2), 346-370.

Kristjanson, P., Mango, N., Krishna, A., Radeny, M., Johnson, N., 2010. Understanding poverty dynamics in Kenya. J. Int. Dev. 22 (7), 978-996.

Kumar, N., Prakash, V., Mina, B.L., Gopinath, K.A., Srivastva, A.K., 2008. Evaluation of toria (Brassica campestris) and lentil (Lens culinaris) varieties in intercropping system with wheat (Triticum aestivum) under rainfed conditions. Indian J. Agric. 53 (1), 47-50.

Kundu, C., Sarkar, R.K., 2009. Effect of foliar application of potassium nitrate and calcium nitrate on performance of rainfed lowland rice (Oryza sativa). Indian J. Agric. 54 (4), 428-432.

Larson, D.F., Otsuka, K., Matsumoto, R., Kilic, T., 2012. Should African Rural development strategies depend on smallholder farms? An exploration of the inverse productivity hypothesis. Development Research Group Policy Research Working Paper 6190. Washington, DC: The World Bank.

Larsson, R., 2005. Crisis and potential in smallholder food production - evidence from micro-level. In: Djurfeldt, G., Holmen, H., Jirstrom, M., Larsson, R. (Eds.) The African Food Crisis. Lessons from the Asian Green Revolution. CABI Publishing, Wallingford, pp. 113-138.

Lin, L., McKenzie, V., Piesse, J., Thirtle, C., 2001. Agricultural Productivity and Poverty in Developing Countries. Extension to DFID, Report No. 7946.

Mann, J.S., Jat, H.S., Kumar, V., Kumar, S., Chaturvedi, O.H., Saha, S., Kumar, D., Bhaka, B.L., 2009. A participatory approach to improve the economic condition of resource poor farmers in semi-arid regions of Rajasthan. SAARC J. Agric. 7 (1), 1 10.

Marer, S.B., Lingaraju, B.S., Shashidhara, G.B., 2007. Productivity and economics of maize and pigeonpea intercropping under rainfed condition in Northern Transitional Zone of Karnataka. Karnataka J. Agric. Sci. 20 (1), 1-3.

MaruthiSankar, G.R., Mishra, P.K., Sharma, K.L., Singh, S.P., Nema, A.K., Kathmale, D.K., Upadhye, S.K., Sidhpuria, M.S., Osman, M., Ravindra Chary, G., 2012 Efficient tillage and nutrient practices for sustainable pearl millet productivity in different soil and agro-climatic conditions. Expl. Agric. 48 (1), 1-20.

Mazvimavi, K., Twomlow, S., 2009. Socioeconomic and institutional factors influencing adoption of conservation farming by vulnerable households in Zimbabwe. Agric. Syst. 101, 20-29.

Moser, C.M., Barrett, C.B., 2003. The disappointing adoption dynamics of a yieldincreasing, low external-input technology: the case of SRI in Madagascar. Agric. Syst. 76, 1085-1100.

MulaRosana, P., Wani, S.P., Thawilkal, W., Thang, N.V., Supama, Y., 2007. Improved Livelihood System of Farm Households through Community Watersheds: Learnings and Insights from Thailand and Vietnam, Global Theme on Agroecosystems Report No. 38, International Crops Research Institute for the Semi-Arid Tropics, Patancheru.

Mustafa, Y., Grando, S., Ceccarelli, S., 2006. Assessing the Benefits and Costs of Participatory and Conventional Barley Breeding Programs in Syria, Working Paper, The International Center for Agricultural Research in the Dry Areas, Aleppo.

Mutanal, S.M., Patil, S.J., Patil, H.Y., Shahapurmath, G., Maheshwarappa, V., 2009 Performance of soybean - safflower under different tree species in black soils. Karnataka J. Agric. Sci. 22 (2), 377-381.

Muyanga, M., Jayne, T.S., Burke, W.J., 2010. Pathways into and out of Poverty: A Study of Rural Household Wealth Dynamics in Kenya. Tegemeo Institute Nairobi.

Naab, J.B., Seini, S.S., Gyasi, K.O., Mahama, G.Y., Prasad, P.V.V., Boote, K.J., Jones, J.W 2009. Groundnut yield response and economic benefits of fungicide and phosphorus application in farmer-managed trials in Northern Ghana. Expl. Agric. 45 (4), 385-399.

Nagayets, O., 2005. Small Farms: Current Status and Key Trends. Information Brief prepared for the Future of Small Farms Research Workshop, Wye College, June 26-29, 2005

Narayan, D.R., Chambers, R., Shah, M.K., Petesch, P., 2000. Voices of the Poor: Crying Out for Change. Oxford University Press, Oxford.

National Economic Council (NEC), 2000a. Profile of Poverty in Malawi, 1998.Poverty analysis of the Malawi Integrated Household Survey, 1997-98, November, National Economic Council, Lilongwe, Malawi.

National Economic Council (NEC), 2000b. Detailed Tables for A Poverty Profile of Malawi, 1998, December, National Economic Council, Lilongwe, Malawi.

Ndjeunga, J., Savadogo, K., 2002. Changes in rural household livelihood strategies and outcomes in Burkina Faso. In: Freeman, H.A., Rohrbach, D.D., Ackello-Ogutu, C. (Eds.), Targeting Agricultural Research for Development in the Semi-Arid Tropics of Sub-Saharan Africa. Proceedings of a Workshop held at Internationa Center for Research in Agroforestry, Nairobi, Kenya 1-3 July 2002, Internationa Crops Research Institute for the Semi-Arid Tropics, Patancheru, pp. 28-47.

Ndjeunga, J., Ntare, B.R., Waliyar, F., Ramouch, M., 2006. Groundnut Seed Systems in West Africa. Common Fund for Commodities (CFC) Technical Paper No. 40,
Common Fund for Commodities, Amsterdam, and International Crops Research Institute for the Semi-Arid Tropics, Patancheru.

Nedunchezhiyan, M., 2010. Performance of greater yam (Dioscorea alata) and maize (Zea mays) intercropping as influenced by mulching and levels of N-P-K fertilization. Indian J. Agric. 55 (1), 28-34.

Nedunchezhiyan, M., Byju, G., Naskar, S.K., 2008. Yield potential and economics of elephant foot yam (Amorphophallus paeoniifolius) and green gram (Vigna radiata) intercropping system as influenced by mulching and fertilizer levels. Indian J. Agric. Sci. 78 (1), 17-20.

Ngigi, M., 2005. The Case of Smallholder Dairying in East Africa, EPT Discussion Paper 131, International Food Policy Research Institute, Washington, DC.

Niehof, A., Rualema, G., Gillespoe, S. (Eds.), 2010. AIDS and Rural Livelihoods: Dynamics and Diversity in Sub-Saharan Africa. Earthscan, London.

Odendo, M., Ojiem, J., Bationo, A., Mudeheri, M., 2007. On-farm evaluation and scaling-up of soil fertility management technologies in western Kenya. In: Bationo, A. Waswa, B., Kihara, J., Kimetu, J. (Eds.), Advances in Integrated Soil Fertility Management in Sub-Saharan Africa: Challenges and Opportunities. Springer, Netherlands, pp. 969-978.

Okalebo, J.R., Othieno, C.O., Woomer, P.L., Karanja, N.K., Semoka, J.R.M., Bekunda, M.A., Mugendi, D.N., Muasya, R.M., Bationo, A., Mukhwana, E.J., 2007. Available technologies to replenish soil fertility in East Africa. In: Bationo, A., Waswa, B., Kihara, J., Kimetu, J. (Eds.), Advances in Integrated Soil Fertility Management in Sub-Saharan Africa: Challenges and Opportunities. Springer, Netherlands, pp. 45-62.

Orr, A., Mwale, B., Saiti-Chitsonga, D., 2009a. Exploring seasonal poverty traps: the 'six-week window' in Southern Malawi. J. Dev. Stud. 45 (2), 227-255.

Orr, A., Adolph, B., Islam, M.R., Rahman, H., Barua, B., Roy, M.H., 2009b. Pathways from Poverty: The Process of Graduation in Rural Bangladesh. University Press Limited, Dhaka.

Ousmane, A., Aune, J.B., 2011. Effect of seed priming and micro-dosing of fertilizer on groundnut, sesame and cowpea in western Sudan. Expl. Agric. 47 (3), 431443.

Prasad, J.V.N.S., Korwar, G.R., Rao, K.V., Srinivas, K., Rama Rao, C.A., Srinivasarao, C., Venkateswarlu, B., Rao, S.N., Kulkarni, D., 2010. Effect of modification of tree density and geometry on intercrop yields and economic returns in Leucaenabased agro-forestry systems for wood production in Andhra Pradesh, Southern India. Expl. Agric. 46 (2), 155-172.

Rao, K.P.C., Kumara Charyulu, D., 2007. Changes in Agriculture and Village Economies. Research Bulletin No. 21. International Crops Research Institute for the Semi-Arid Tropics, Patancheru.

Ravallion, M., Chen, S., Sangraula, P., 2008. Dollar a Day Revisited. Policy Research Working Paper No. 4620, World Bank, Washington, DC.

Rural Solutions SA, 2010. Farm Gross Margin Guide 2010. Government of South Australia. <www.ruralsolutions.sa.gov.au>.

Sen, B., 2003. Drivers of escape and descent: changing household fortunes in rural Bangladesh. World Dev. 31 (3), 513-534.

Sheoran, P., Sardana, V., Singh, S., Bhushan, B., 2010. Bio-economic evaluation of rainfed maize (Zea mays)-based intercropping systems with blackgram (Vigna mungo) under different spatial arrangements. Indian J. Agric. Sci. 80 (3), 244 247.

Shiferaw, B., Silim, S., Muricho, G., Audi, P., Mligo, J., Lyimo, S., You, L., Christiansen, J.L., 2005. Assessment of the Adoption and Impact of Improved Pigeonpea Varieties in Tanzania. Working Paper Series No. 21. International Crops Research Institute for the Semi-Arid Tropics, Patancheru.

Shiferaw, B., Muricho, G., Okello, J., Kebede, T.A., Okecho, G., 2010. Adoption of Improved Groundnut Varieties in Uganda. Markets, Institutions and Policies, Research Report No. 5, International Crops Research Institute for the Semi-Arid Tropics, Patancheru.

Shiyani, R.L., Joshi, P.K., Bantilan, M.C.S., 2001. Impact of Chickpea Research in Gujarat. Impact Series No. 9, International Crops Research Institute for the Semi-Arid Tropics, Patanceru.

Simtowe, F., Asfaw, S., Shiferaw, B., Muricho, G., Abate, T., Rao. G., Siambi, M., Moyo, E., Silim, S., 2010. Socio-economic Assessment of Pigeonpea and Groundnut Production Conditions - Farmer Technology Choice, Market Linkages, Institutions and Poverty in Rural Malawi, Markets, Institutions and Policies Research Report No. 6, International Crops Research Institute for the Semi-Arid Tropics, Patancheru.

Singh, S.R., Singh, U., 2008, Efficacy of vesicular arbuscular mycorrhizae as influenced by phosphorus application in wheat (Triticum aestivum) under rainfed conditions of Kashmir. Indian J. Agric. Sci. 78 (9), 771-776.

Singh, R.S., Yadav, M.K., 2008. Effect of phosphorus and biofertilizers on growth, yield and nutrient uptake of long duration pigeonpea under rainfed condition. J. Food Legumes 21 (1), 46-48.

Singh, H.N., Pandey, S., Villano, R.A., 2000. Rainfed rice, risk, and technology adoption: microeconomic evidence from eastern India. In: Tuong, T.P., Kam, S.P., Wade, L., Pandey, S., Bouman, B.A.M., Hardy, B. (Eds.), Characterizing and understanding rainfed environments. Proceedings of the International Workshop on Characterization and Understanding Rainfed Environments, 5-9 December 1999, Bali, Indonesia, International Rice Research Institute, Los Banos, Philippines, pp. 323-337.

Singh, G., Singh, O.P., Singh, S., Prasad, K., 2010. Weed management in late sown wheat (Triticum aestivum) after rice (Oryza sativa) in rice-wheat system in rainfed lowland. Indian J. Agric. Sci. 55 (2), 83-88.

Tabo, R., Bationo, A., Gerard, B., Ndjeunga, J., Marchal, D., Amadou, B., Annou, M.G., Sogodogo, D., Tonda, J.-B.S., Hassane, O., Diallo, M.K., Koala, S., 2007. Improving cereal productivity and farmers' income using a strategic application of 
fertilizers in West Africa. In: Bationo, A., Waswa, B., Kihara, J., Kimetu, J. (Eds.), Advances in Integrated Soil Fertility Management in Sub-Saharan Africa: Challenges and Opportunities. Springer, Netherlands, pp. 201-208.

Thorner, D., 1981. The Relevance of Entrepreneurial Economics to Production by Peasant Households. In: Thorner, D. (Ed.), The Shaping of Modern India. Allied Publishers Private Limited, New Delhi, pp. 292-309.

United States Department of Agriculture (USDA), 2009. Economic Research Service. <http://www.ers.usda.gov/data/costsandreturns/testpick.htm>.

Wanjala, B.M., Muradian, R., 2013. Can big push interventions take small-scale farmers out of poverty? Insights from the Sauri Millennium Village in Kenya. World Dev. 45, 147-160.
Woomer, P.L., 2007. Costs and returns of soil fertility management options in Western Kenya. In: Bationo, A., Waswa, B., Kihara, J., Kimetu, J. (Eds.), Advances in Integrated Soil Fertility Management in Sub-Saharan Africa: Challenges and Opportunities. Springer, Netherlands, pp. 881-889.

World Bank, 2008. Poverty Data. A supplement to the 2008 World Development Indicators, World Bank, Washington, DC.

Yusufali, A.N., Alagundagi, S.C., Mansur, C.P., Hosamani, S.V., Mummigatti, U.V. 2007. Effect of date of sowing and seed rate on fodder production potential and economics of Field Bean genotypes under rainfed condition. Karnataka J. Agric. Sci. 20 (1), 13-16. 